\title{
Exploring The Nexus Between Family Size Planning and Retirement Planning in Ghana
}

\author{
Delali Adjoa Dovie \\ University of Ghana - dellsellad@gmail.com
}

\begin{abstract}
The study articulates the perspectives and attitudes of workers in an attempt to uncover thoughts and ideas in relation to the phenomena of family size planning and retirement planning. Use was made of both quantitative and qualitative datasets. The sample [ $n=442]$ was selected using a multi-stage sampling technique. The paper finds that there is a link between family planning and retirement planning. The reasons for this nexus encompass the fact that large family sizes may inhibit saving abilities. Further, large family size hinders the ability to save. The ideal family size in this context ranges between 1 and 5. The findings show that family planning positively corre-

lated (0.688) with retirement planning. Stated differently, family size correlates with planning towards retirement to a greater extent. Whereas large family size inhibits retirement planning, small family size facilitates less expenditure and better savings, and ensures the availability of financial resources to be channeled into retirement plans. These findings reflect a change in thoughts regarding large family size as opposed to small family size. A gradual shift pertains to smaller families with retirement planning in focus. Also, annexed to family planning is social relationship building, both of which have implications for later life planning.
\end{abstract}

Keywords: Family size planning, social relationship building, retirement investments, workers, retirement planning

\section{Explorando o Nexo entre o Planeamento Familiar e o Planeamento da Reforma no Gana}

\begin{abstract}
Sumário
O estudo articula as perspetivas e atitudes dos trabalhadores, procurando descobrir pensamentos e ideias em relação aos fenómenos do planeamento familiar e do planeamento da reforma. Utilizaram-se conjuntos de dados quantitativos e qualitativos. A amostra [ $\mathrm{n}=$ 442] foi selecionada, usando uma técnica de

amostragem em vários estágios. O artigo conclui que existe um elo entre o planeamento familiar e o planeamento da reforma. As razões para esse nexo incluem o fato de que famílias de dimensão elevada apresentarem inibição na capacidade para economizar. Além disso, o tamanho de uma família de dimensão ele-
\end{abstract}




\section{Exploring The Nexus Between Family Size Planning and Retirement Planning In Ghana}

vada dificulta a capacidade de economizar. O tamanho ideal da família nesse contexto varia entre 1 e 5 . Os resultados mostram que o planeamento familiar correlacionou-se positivamente $(0,688)$ com o planeamento da reforma. Por outras palavras, o tamanho da família correlaciona-se, em grande medida, com o planeamento para a reforma. Enquanto o tamanho da família grande inibe o planeamento da reforma, o tamanho da família pequena possibilita menos gastos e melhores economias e garante a disponibilidade de re- cursos financeiros canalizados para os planos de reforma. Esses resultados refletem uma mudança de pensamento, em relação ao tamanho da família grande, em oposição ao tamanho da família pequena. Observa-se uma mudança gradual nas famílias de menores dimensão focadas no planeamento da reforma. Também juntamente com o planeamento familiar figura a construção de relações sociais, as quais têm implicações para o planeamento posterior da vida.

Palavras-chave: Planeamento familiar, construção de relacionamento social, investimentos em reforma, trabalhadores, planeamento de reforma.

\section{INTRODUCTION}

Preparing towards post-retirement life is constituted by nine distinct pillars. First, it consists of a series of processes that first and foremost depend on negotiating the process of retirement preparation namely the identification of retirement aspirations. Second, pre-retirement education (PRE), the foundation of the whole process. This relates to what is to be anticipated in preparing for retirement including what to do. Third, the ranking of needs; fourth, resource mobilization; fifth, pension contribution. Sixth, the institution of emergency account strategy that comprises savings and 'susu'. Seventh, involves wealth creation through the investment of funds into financial products such as treasury bills, shares, stock, bonds, fixed deposits, purchase of house(s), and Medicaid. Eighth, family planning and social relationship building. Finally, resource allocation aimed at resource utilization extensively in post-retirement life. Noteworthy is that these can be collectively pursued (Dovie, 2018a). The implication of this is that retirement planning is a continuous process in the life course.

Resource mobilization for later life is not the preserve of pension participation and contribution but an all-encompassing institution of a myriad of portfolios such as T-bills, shares, insurance policies among several others, all of which may complement pension income. When undertaken, these serve as a buffer against having to solely depend on pension contributions for old age income and thus ensuring eco- 
nomic security (Dovie, 2018a). After the event of retirement, the resources mobilized can be utilized in diverse ways. For instance, needs situated within the context of post-retirement life may be ranked during which economically viable decisions can be taken. This can be attained through the identification of problems such as an impending health challenge, for which the mobilized resources may be used. This means that retirement planning is a continuous process in the life course.

Retirement planning is the diverse preparations and preparation portfolios workers institute during active service in anticipation of life after retirement (Agbobli, 2011; Moody, 2010; Novak, 2006). It may occur at both the organizational and individual levels comprising savings and the accumulation of assets among others (Dovie, 2017). Retirement planning consist of family planning and the allocation of resources for designated purposes namely purchase of houses (Dovie et al., 2018; Dovie, 2019a, 2019b, 2019c) or paying for the education of children while simultaneously instituting retirement plans and portfolios (Dovie, 2018a). Preparation towards retirement also entails family planning and social relationship building which takes three distinct forms namely having a manageable family size, care for own children, care for siblings and/or cousins as well as joining association(s). These can be collectively pursued.

Atchley (2000), Litwin (2010), and Quadagno (2014) write that social network ties stem from several sources such as the family and the work place including social exchange in terms of the receipt of informal time (practical aid) and/or financial transfers. The essence of family planning lies in the fact that there is the need to have a closer and tight web of social relations to serve as a buffer in the event of retirement, while having enough financial resources devoted to retirement planning. Essentially, this type of web must be built meticulously and with maximum care in order to avoid the spate of loneliness that may ensue during years of retirement, due to the lack of a formidable network of social relationships with immediate family relations and significant others Dovie, 2018a).

Freifeld (2013) documents that positive and supportive relationships will help individuals to feel healthier, happier, and more satisfied with life. More positive and healthy relationships can be fostered by the following in all areas of life: first, accepting and celebrating differences; second, listening effectively and understanding what others communicate to people is the most important part of successful interaction and vice versa. Third, giving time to people as also a huge gift. Devoting time, energy, and effort to developing and building relationships is one of the most valuable life 


\section{Exploring The Nexus Between Family Size Planning and Retirement Planning In Ghana}

skills. Fourth, the development of communication skills is imperative. Fifth, mobile technology management is key. Mobile gadgets save lives in an emergency, and effective tools for communication. Yet, they also can be a complete distraction when people exhibit a lack of mobile phone etiquette. Lastly, learning to give and take feedback. Feedback is the food of progress. Learning to trust more, and developing empathy are also worth pursuing.

Rappaport (2017) notes that the extended family is an important part of retirement planning for many Americans. Indeed, in the past, family members frequently helped fill in gaps when people grew older. Yet today, people increasingly reach their senior years with few or no family members who can assist. Perhaps, family concerns are often given inadequate consideration in retirement planning. A study conducted by the Employee Benefit Research Institute (2019) showed that 51\% of Americans aged 50-64 provide financial assistance to their family members. The proportion dropped at older ages: $39 \%$ of those aged $65-74,33 \%$ of those age $75-84$, and $85+$ (28\%). But only a handful of older households (5\%) received financial transfers from younger family members.

Greenwald and Associates (2013) conducted detailed focus groups with people in the US and Canada who have retired for 15 years or more. The findings comprised the fact that many long-term retirees have managed their finances in retirement quite well. Yet some financial shocks proved particularly unsettling, including needing long-term care and getting a divorce in retirement. A cross section of the retirees did not want to rely on their children for support, while others perceived their children as a potential resource to fall back on. Presently, most seniors do not plan on having their children help them, and many work hard to avoid it. Nonetheless, many family members can and do provide help (Rappaport, 2017). A problem frequently mentioned by long-term retirees arises when adult children need help, for instance due to mental illness. Some seniors also have dependent children or grandchildren living with them, and some help pay for their off springs' education.

Sun, Barboza, and Richman (2007) document that personal retirement planning behavior is a function of access to investment information albeit from digital literacy sources. Pre-retirement education (PRE) prioritizes advancement and achievement in relation to retirement preparations (Dovie, 2018b). There is therefore a significant relationship between PRE and retirement planning for which there is the need to disseminate information in order to inspire, inform and foster learning and knowledge acquisition. However, inadequate access to information, ineffective management and 
dissemination of information has been an enduring challenge (Amoakohene, 2011; Dovie 2018b, 2018c), traversing both colonial and post-independence eras (Amoakohene, 2011). Stated differently, PRE fosters family size planning.

The goal of this paper is to articulate the essence of family size planning, social relation building and how they are related to retirement planning. The study set out to ascertain the correlation between family size planning and retirement planning. The objectives of the study are: to investigate the influence of family planning on retirement planning; and to outline social relationship formation within the context of retirement planning.

The remainder of the paper is ordered as follows: section two documents issues related to retirement and family planning in Ghana and work dynamics in the formal and informal sectors. Section three entails theoretical framework, section four discusses the methods employed in the study, section five presents study results, section six discusses the results and section seven concludes the paper.

\section{RETIREMENT AND FAMILY PLANNING IN GHANA}

Temporal shifts in old age family support and differences exist between populations pertain regarding the extent to which families provide support to older people (Deatland \& Harlfson, 2003). For instance, observed differences between western nations and some non-western societies including Africa and Ghana exist in terms of extreme lack of family support (Aboderin, 2005). The weakening of the norms of family and filial obligation is due to the influence of western individualistic values and urban lifestyles and a consequent growing focus on the nuclear family (Aboderin, 2004). Aboderin (2004, p. 226) further argues that it would represent an attempt to lay down a particular 'moral order' of family responsibilities that no longer fully accord the values and expectations for the future, prevalent in the population today.

Dovie (2018a) opines that what retirement was yesterday is not what it is today, or what it will be in the future. In contemporary times, life expectancy is higher today than ever before. Also, poor financial planning for retirement is reported to be a major problem among formal and informal sector workers and may compound the overdependence documented among elderly individuals (de-Graft Aikins et al., 2016, p. 176). In addition, not planning towards retirement may engender vulnerability to economic dependence in later life. 


\section{Exploring The Nexus Between Family Size Planning and Retirement Planning In Ghana}

Retirement is an inevitable life transition (Dovie, 2018a) which requires advance preparation. Previously in Ghana, the traditional social support system played a key role in the care of older people. Aboderin (2006) notes that inadequacies in material family support and concerns over old age economic security, which leaves many older people unable to meet their basic needs. Retirement planning is a pertinent issue in Ghana, especially with increased life expectancy in recent times. It is for this reason that Dovie (2017) found that $86 \%$ of workers were planning for retirement with implications for the realisation of retirement aspirations of workers, availability of adequate planning information, salary increment, all of which have effects on retirement investments. Similarly, Bokpin (2018) asserts that Ghanaian workers in active service need to be educated to plan for their retirement before the attainment of the retirement age of 60 years. This is attainable with the provision of retirement planning information, particularly by pension service providers (PSPs) as well as related organisations and/or institutions (Dovie, 2017, 2018a, 2018b). Worldwide, pension systems and the attendant contributions constitute a key mechanism for preparing towards retirement (Dovie, 2018b), the significance of which cannot be underestimated including the security of ageing populations (Holzmann \& Hinz, 2005).

Population pressures depict significant constraints on future economic growth and the ability of the country including Ghana to provide the welfare of its citizens and achieve its national development objectives (GAP, 2012). Ghana's population increased by $30 \%$ from 18.9 million in 2000 to 24.6 million in 2010 . It is against this backdrop that the government of Ghana took cognizance of the link between rapid population growth and social and economic development to foster a positive policy environment for family planning. For instance, the road map for repositioning family planning in Ghana (2006-2010) beacons for an increase in political commitment and public awareness, and the acceptance of family planning as important to national health and socio-economic development including funding for family planning commodities and services.

The National Population Policy (Revised Edition, 1994) also sets clear targets in relation to fertility-contraceptive use. In furtherance to the proceeding family planning policies, the national blueprint for development, the Ghana Shared Growth and Development Agenda (2010-2013) reorganized family planning as a key priority for inclusion in national development plans and activities at all levels (GAP, 2012).

Also, the 2008 Demographic and Health Survey (DHS), (2008) intimates that Ghana's total fertility rate reduced to an average of 4 children per woman and the 
utilization of modern family planning methods among women within the 15-49 age range increased to $17 \%$, yet fertility rates vary across the country, rising from 2-5 children per woman in the Greater Accra Region to 6.8 children in the Northern Region of Ghana. Considering such high fertility rate in Ghana, the study sought to ascertain the extent of integration between retirement planning and family size planning, and the influence thereof.

\section{FORMAL AND INFORMAL SECTOR WORK DYNAMICS}

The field of work is constituted by formal and informal sectors (Dugbazah, 2012; Ghana Statistical Service, 2013; Round, 2009). The formal sector comprises private formal and public formal sectors. According to Ackah et al, (2012) the public sector forms a major part of the formal sector. In all societies, the two forms of economic activities namely formal and informal sector activities exist side by side. However, in other contexts, they overlap. The key distinction between formal and informal employment opportunities is the difference between workers who earn monthly salaries and those who are self-employed and yet do not enjoy opportunities in terms of monthly salaries. The key characteristics of the formal sector entail operation under the support of accepted rules and regulations that have been enacted and implemented by government (Chen, 2007; Addai, 2011).

The majority of the labor market in Sub-Saharan Africa (SSA) is self-employed in the informal sector including agriculture and non-farm work (Palmer, 2007). The informal sector in Ghana is a loose combination of small-scale organizations and people who are self-employed (Addai, 2011; Palmer, 2007), who operate independently of the rules and regulations that the formal sector is endowed with. This is indicative of the fact that the informal sector does not provide its employees with 'privileged facilities' existent in the formal sector (Chen, 2007; Round, 2009; Addai, 2011), such as pension contributions, medical coverage, end-of-service benefits (Dovie, 2019a) It may not also comply with the minimum wage payment regulations and to some extent does not have plans and benefits e.g. social security (Round, 2009) for its employees in terms of retirement or compensation for its employees in the case of the termination of appointments (Addai, 2011; Round, 2009), yet not necessarily. This depicts engagement in vulnerable employment with high level of informality in the labor market (Ackah \& Baah-Boateng, 2012). It has been observed that it is difficult 


\section{Exploring The Nexus Between Family Size Planning and Retirement Planning In Ghana}

for the informal sector to secure credit (Round, 2009; Dugbazah, 2012). Workers in this sector are forced to accept cash-in-hand wages (Round, 2009) or that informal payments are demanded in order to secure employment not necessarily by chance (Round, 2009; Dugbazah, 2012).

Only $20 \%$ of Ghana's active population is employed in the formal sector (GSS, 2010), which is characterised by rules and regulations in relation to working conditions (Addai, 2011; Chen, 2007; Round, 2009) including monthly salaries (Addai, 2011). The informal sector employs $80 \%$ of Ghana's population (Doh, Afranie, \& Bortei-Doku Aryeetey 2014; Osei-Boateng \& Ampretwum, 2011; Tonah 2009). Inherent in the informal sector are poor pay; lack of formal job descriptions including terms and conditions of service (Chen, 2007; Round, 2009; Tsikata, 2015). Compared to their informal sector counterparts, formal sector workers are mandatorily compelled to prepare towards retirement via pension contributions. But there is no fixed age for retirement in the informal sector, except dictated by ill-health or frailty.

\section{THEORETICALFRAMEWORK}

The theoretical framework that underpins this study is a medley of the stages of retirement theory as well as Caldwell's wealth flow theory.

The stages of retirement theory, according to Atchley (2000) has several phases, pertinent among which is the pre-retirement planning phase which this study adopts. This phase occurs prior to the event of retirement. The pre-retirement phase of the theory articulates planning along the life course, constituted by the remote and near stages, each with distinguished features and sets of actions to be undertaken. However, the stage of essence here is the near stage.

The near stage is usually characterized by anticipation of and planning for retirement. This stage occurs almost immediately before retirement. At this stage, workers plan on retiring from work and check on retirement investments. These depict planning for retirement along the life course. At this stage, workers prepare to separate from the workforce and work context, develop detailed retirement aspirations and expectations. Yet, Atchley (2000) argues that the most significant retirement preparation measure is financial planning, which in this context finds expression in PRE. It relates to financial planning including health and life-style topics; legal issues; housing information and work after retirement. However, Atchley's theory failed to clearly 
articulate social relationship development platforms such as family size planning, family, associational membership among several others and the significance thereof. This shortfall is supplemented by the wealth flow theory postulated by Caldwell $(1976,1978,2005)$.

Caldwell (1978) argues that the incentive for childbearing is determined by the economic value of children and the attendant direction of the flow of intergenerational wealth. High fertility rates exist in developing countries, yet the explanation and offering of contraceptives has yielded little improvement (Caldwell, 2005). To some extent, these change with the emergence of modernization, industrialization as well as change in the orientation of the individual (Caldwell, 1976) and the entire process of economic and social development. Nevertheless, the survival of children born is important, but equally essential is the fact that such children are well-spaced and by extension, families limit the number of children born. Caldwell (2005) argues thus, the pressure to have fewer children results principally not from forward-looking educated parents but from forward-looking investing parents (p. 736).

The underlying principle for childbearing and the associated economic value is expressed in the fact that societies and therefore parents are economically rational. Normally, services have obligatory elements, albeit investments in future security. However, this notion turns out more in African societies wherein parents allegedly bear children who are socially bound by the rationality of an economic goal in the form of social insurance in old age. Caldwell (1976) argues that no matter the type of society, children have a myriad of demonstrable values expressed in doing enormous work for and with their parents both at a younger age. In order to increase the ability of their children to make returns, parents invest in the training or education of their children. Wealth flow may be direct and indirect. The indirect routing of wealth flow pertains to the augmentation of political strength to allow the tapping of a larger share of communal wealth (p. 344). Caldwell (1978) termed this 'reversal of intra-familial wealth flow'

Caldwell (1976) documents that the net flow from children to parents is the predominant situation in primitive and traditional societies, for example among the Yoruba in Nigeria, yielding substantial returns. In addition, parents' payment of their children's educational expenses denote an investment beyond which other motives such as the pride of parents, family honor, valuation and appreciation of children in marriage pertains. Culturally, people do not save money for retirement. Instead, they invest in their children, a notion that gives credence to Caldwell's intergenerational 


\section{Exploring The Nexus Between Family Size Planning and Retirement Planning In Ghana}

transfer conception, signifying the diversification of retirement resources. This assertion of Caldwell's indicates that in the absence of other investments, a significant reaction to risk in old age is caring for children. Children's insurance value in times of disaster, danger and old age of parents (Caldwell, 1976, 2005) cannot be underestimated. Thus, Caldwell demonstrated the insurance potential of children to be an equivalent of current payments for an insurance policy which is normally redeemed at a future date. As Caldwell (2005) notes, the insurance role is more important than the investment role (p. 724). However, the wealth flow theory ignored workers' investment in significant others in society. This study fills this gap.

\section{RESEARCH METHODS AND DATA ANALYSIS}

Tema is a typical major Ghanaian city that is privy to and epitomizes an urban setting, it which articulates the deepened prongs of family planning vis-à-vis retirement planning among workers. Data for this paper was collected as part of a bigger research project. This project was for the award of a $\mathrm{PhD}$ degree in Sociology and was focused on the preparations of Ghanaian formal and informal sector workers towards retirement. The data collection took a cumulative period of 16 months, from October 2015 to January 2017.

\section{Subjects and Settings}

The explanatory sequential mixed methods strategy was employed in this study. Using a three-phase approach, the study gathered both quantitative and qualitative datasets. The initial qualitative phase explored institutional level viewpoints regarding issues of retirement planning generally in Ghana. The sample at this phase like the third phase were purposively selected. Noteworthy is that information obtained from this phase was used to guide the development of the questionnaire for the subsequent phase. The second quantitative phase ascertained workers' general views on retirement planning from the trajectory of family size planning and its relationships to retirement based resource mobilization. A multi-stage clustered sampling technique was used to select a sample of 442 workers aged 18-59 years utilizing the formula by Moore and McCabe (1993). An anticipated non-response was built into the survey design. Further, organizations were first stratified into formal and informal sectors, afterwards they were then clustered into manufacturing, administrative and service 
organizations. Out of these, the administrative and service units were randomly selected. From these, individual workers were also randomly selected. Thus, the total population of Tema according to Ghana Statistical Service (2014) is 292,772, out of which 135, 640 are employed, and it was from this that the sample for the study was selected. The third phase of the study sought to understand the lived experiences of workers' retirement preparation from the tangent of family size planning and social relationship building based lived experiences. The University of Ghana's Institutional Review Board approved the project. Confidentiality and anonymity were ensured.

\section{Data Collection Process}

Key informant interviews were used in the first phase of the study with 12 institutional participants. A questionnaire was used in data collection in the second phase. Furthermore, the survey was used because of the coverage of wide numbers of respondents it facilitates. The administration of the questionnaire took the form of face-to-face interviews to eliminate the situation of unreturned questionnaires. To facilitate this, interview appointments were booked severally, even five or six times. As indicated earlier, the questionnaire for this phase was influenced with findings from phase 1.

During the third phase, 20 respondents who had participated in the initial phase also took part in follow up interviews with the purpose of obtaining an explanation for issues raised in the prior phase. In-depth interviews were used in the gathering of data. Prior to which permission to tape record discussions including informed consent were sought. The questionnaire was created based on previous research (Agbobli, 2011), input from colleagues and also the study's research interests. After the initial pool of questionnaire was written, qualified experts reviewed and made suggestions for improvements. To ensure reliability of the instrument, it was pretested on a sample of 30 individuals, following the guidelines of (Perneger et al., 2015). Further, a pilot test among the intended respondents for initial validation was undertaken.

The interview guides and questionnaire were piloted to ensure accuracy in understanding, fluency and proper wording of questions. The face-to-face interviews were conducted in both English language and Ghanaian languages, namely Ga, Ewe and Twi. 


\section{Exploring The Nexus Between Family Size Planning and Retirement Planning In Ghana}

\section{Data Analysis}

The key informant and in-depth interviews were preliminarily analyzed as they were being collected based on which modifications were made in the sampling strategy before the next series of interviews to ensure gaps were ascertained and rectified. This act preserved the multivocality and complexity of lived experiences while maintaining focus on the study's theme. The qualitative data analysis process was undertaken following Bryman's (2008) analysis strategies. Therefore, a combination of the following analytic strategies was employed in this study. First, analytic induction, which was related to reaching general explanations, was used. Second, thematic analysis was undertaken in relation to the examination of theoretical themes of the research through studying particular cases. Finally, narrative analysis was used to search for new issues from the stories told by the research participants about their lives.

Efficiency of the thematic analysis conducted was ensured following a variety of principles in the course of data processing. These include the search of similar and different responses among interviewees on given themes such as family planning and social relationship building dynamics; transitions in search for issues that link themes and sub-themes together. These were undertaken to ensure the pursuance of the relationship between categories and themes of data seeking to increase the understanding of the phenomenon.

Nvivo Software was used to facilitate text coding and retrieve coded texts as well as interpret the data. In lieu of which the analytical process proffered by Bazeley and Jackson (2014) was followed, using five distinct steps. A project was created which comprised all the documents, coding data and related information that assisted in the process of data analysis as well as saving the NVivo project. The transcribed interview files were respectively named. Qualitative data files were imported. Additionally, nodes were engaged as a place in NVivo for references to code text.

A chunk of data were then coded. This included finding obvious themes as well as auto-coding. The codes formed a pattern. The passages of texts were compared and contrasted for ways in which they were similar and different. The emergent concepts, entailed for example, family planning and its attendant influence retirement planning. Memos were used to tell the story of the research by adding descriptions. The knowledge developed from the data was reported.

The themes appeared as major findings and were used to create headings in the results section of the paper. The interrelation between themes involved the use of narrative passage to convey the findings of the analysis. The themes were interconnected into a storyline. 
The obtained quantitative data were analyzed utilizing Statistical Package for Social Science Software (SPSS) version 20.0, using frequencies, percentages and bivariate analysis - Pearson product moment chi-square and Cramer's V tests were as the standard to assess the correlation between the two variables studied. The usage of multi-stage sampling approach means that the results are statistically representative, thus, generalizability is permissible to the general population.

\section{RESULTS}

The study population consisted of 213 males (48.2\%) and 229 females (51.8\%) aged between 18-59 years. Most of the respondents had some level of education. Overall, the highest educational level attained by a near majority of the respondents (46.4\%) was tertiary education. They were constituted by the formal sector $(221,50 \%)$ and informal sector workers $(221,50 \%)$ (Table 1$)$.

Table 1

Participants' demographics

\begin{tabular}{cccc}
\hline Variables & Characteristics & Frequency & Percent (\%) \\
\hline \multirow{2}{*}{ Age } & $18-24$ & 21 & 4.8 \\
& $25-29$ & 42 & 9.5 \\
& $30-34$ & 81 & 18.3 \\
& $35-39$ & 58 & 13.1 \\
$40-44$ & 67 & 15.2 \\
& $45-49$ & 59 & 13.3 \\
Sex & $50-54$ & 54 & 12.2 \\
& $55-59$ & 60 & 13.6 \\
Educational level & Male & 213 & 48.2 \\
& Female & 229 & 51.8 \\
& No-formal education & 24 & 5.4 \\
Sre-tertiary education & 212 & 48.0 \\
& Tertiary & 206 & 46.4 \\
\hline
\end{tabular}

Note. Data must be read as percentages. Source: Field data, 2016. 


\section{Exploring The Nexus Between Family Size Planning and Retirement Planning In Ghana}

\section{The notion of family size planning}

Formal sector (72.4\%) and informal sector $(27.6 \%)$ workers, planned the number of children they wanted to have (Figure 1) as part of the retirement planning process. In other words, some of the workers had an anticipated number of children they could adequately care for. This could be expressed as the intended number of children for the worker/or planners.

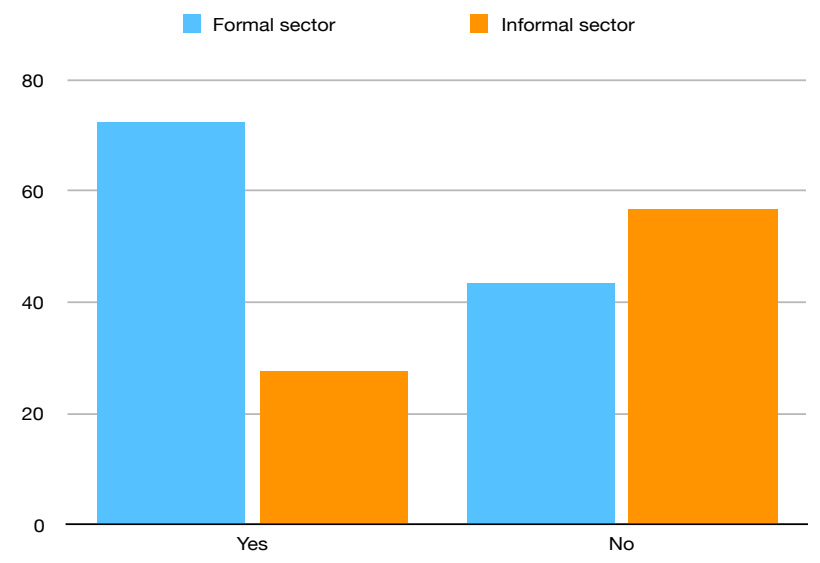

Figure 1. Planned number of children had. Source: Field data, 2016

The key informant interview data reveal that family planning is a phenomenon that is undertaken with the focus to plan well towards retirement. It is an epitome of the prioritization of the needs of which sensitization is imperative. This is summarized as follows:

I don't know because we have misplaced priorities. I for one, I bought a house before I bought a car. I know you see, because I know if they sack me from here now, I can rent it and go and get a 2 by 4 place at the United Nations and stay and still be getting money without working. You see, when you go to the rural areas they like buying cloth, every new cloth they will go and buy for any funeral, meanwhile they don't look after their children to go to school. It's the education that should start, that people should plan, planning in everything. Planning, the keyword is planning. They should plan for their future, even the number of children they want to have. They should plan, the number of children they want to have, they should not have 5,6,7,8 in this day and age (Key informant 1). 
The above quote emphasizes the need to plan a family size necessitated by later life and facilitated by sensitization to do so particularly by pension service providers and a host of others. In other words, retirement planning is strengthened and/or consolidated with the provision of planning information. The survey data indicates that the desired family size ranges between 1 and 5 in terms of the number of children had, yet dependent on the individual (Figure 2), according to formal (76.2\%) and informal (23.8\%) sector workers, the highest number of children should be 5 . In other words, the desired family size ranges between 1 and 5, whereas the highest number of children is 5 . It is worthy of note that the members of the family are not only the children but parents or guardians as well. Hence, at least in the case of single parent families, size family ranges between 2 and 5 . However, inasmuch as a family of 5 elements may depict a small family in Ghana, it may not actually denote a small family elsewhere including Europe. The criteria to define small and large families in the context of this study relates to the following: in marriages the couple and a child, yielding a family of 3 elements as constituting a small family whereas large families may entail a couple and 4 or more children; a single parent and 4 or more children.

It is worth reiterating the fact that annexed to family planning is the phenomenon of social relationship formation with children, siblings, cousins as well as significant others. These have been vividly described below.

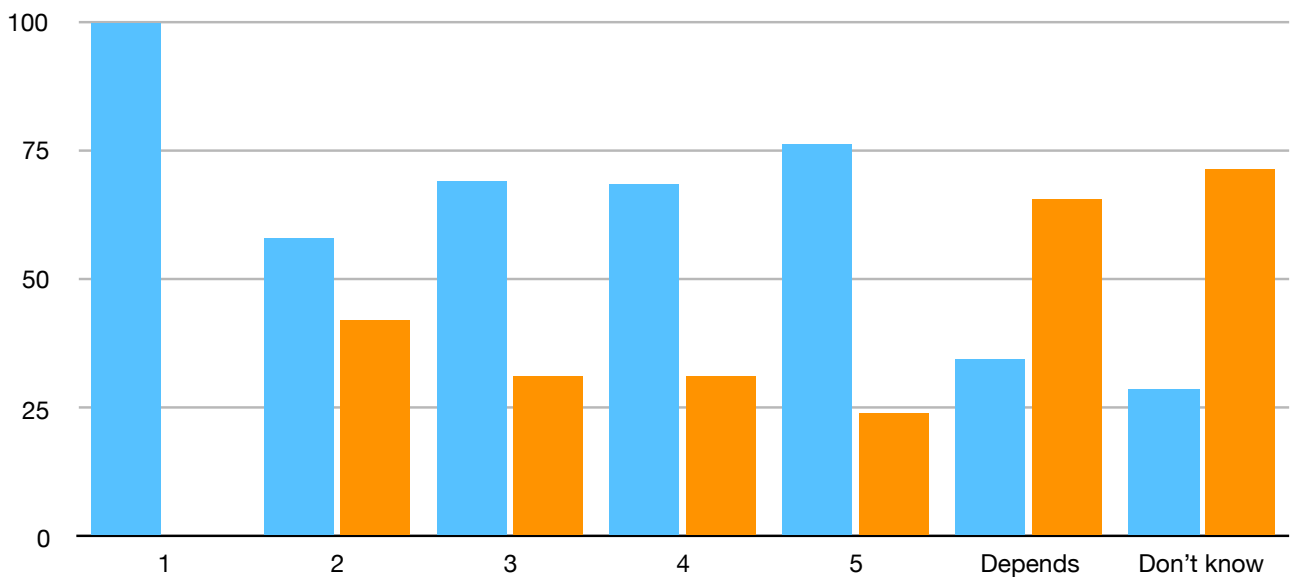

Figure 2. Ideal number of children for retirement planning. Source: Field data, 2016 


\section{DYNAMICS OF FAMILY PLANNING AND RETIREMENT PLANNING}

The key informant interviews intimate the observation that, essentially preparing for retirement should begin at the commencement of gainful employment. Further, family size planning has implications for retirement preparation. This is because people bear more children for old security. However, in contemporary times, smaller sizes are becoming the norm. Annexed to this is the adequate spacing of children. It also suggests that there is a link between family size and retirement preparation.

The survey data found out that more informal sector workers (54.3\%) felt that the link between the two variables is a lot (Figure 3). In other words, they are of the view that there is a strong connection between the variables involved.

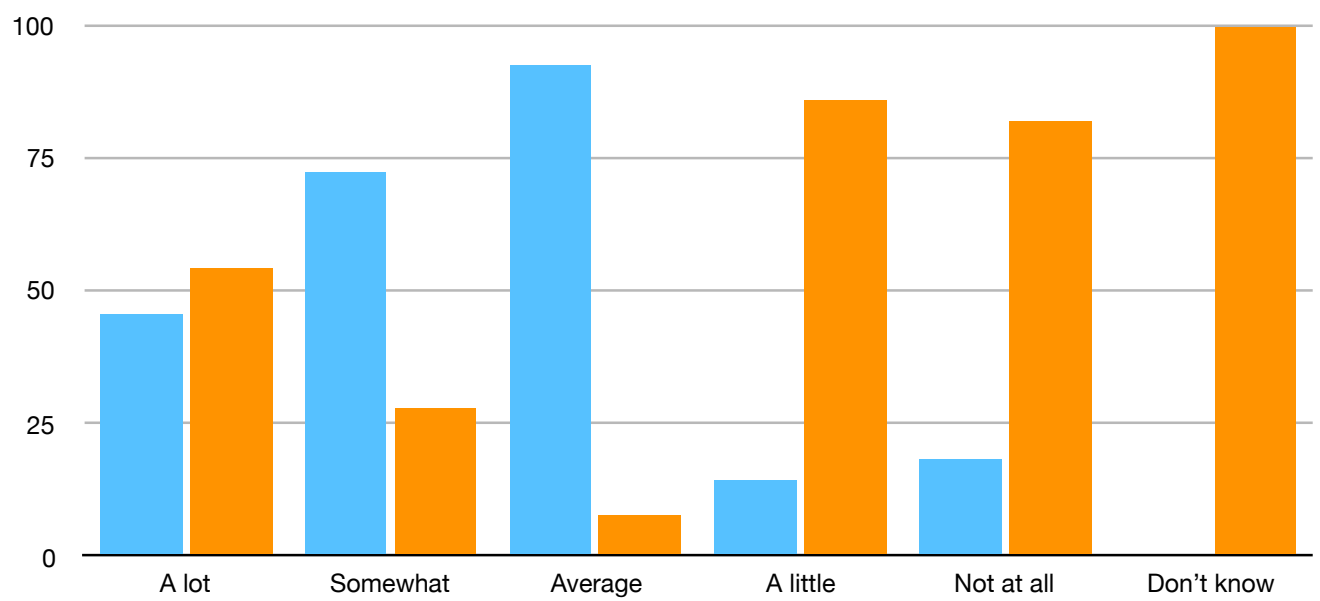

Figure 3. The extent of connection between family planning and retirement planning. Source: Field data, 2016

The in-depth data brings to the fore reasons for the linkage between family (size) planning and retirement planning as entailing the fact that larger family sizes may inhibit saving abilities, determine the planning mode, the need to increase savings, traditional belief, family size determines the extent of living expenditure, kind of work, financial status or income among others. These denote extended family preferences, 
emphasizing the size of the family including the fact that the issue of family size can be digressed on without being context specific. These reasons have been expressed as follows:

Large family size hinders one's ability to save (Formal male).

One's family size will determine how the planning will be (Informal female).

But it depends on the situation (Formal male).

In Ghana, we believe in extended family relationships. Therefore, even when you are on retirement, family members will solicit financial assistance from you (Informal male).

This is because if your family is large you have to increase the savings habit (Informal female)

This is because of expenditure. The lesser the expenditure, the better the savings (Formal male).

A small family size ensures the availability of financial resources to be channeled into retirement plans (Formal male).

Smaller families can easily save something towards retirement (Informal female).

Family size will determine one's planning towards retirement (Informal male).

By contrast other observations articulate the fact that retirement planning and family size denote a third force of a kind. For example:

Both are representing a third force of the likelihood hence they are not closely linked (Formal female).

Not at all, it does not matter one's family size, one can still plan and plan well (Informal female)

These statements are reminiscent of a change in thought in terms of small family size and retirement planning. This is because through these financial resources are made available that could be invested in other retirement planning portfolios such as susu, T-bills, shares, mfund, epack, pension contribution, house and land acquisition, medicare and a host of others. However, a larger family size was in vogue in the immediate past, where large families served the economic purpose of laborforce. Yet, in contemporary times, there has been a gradual shift to smaller families with 'retirement planning in focus'. Also, reasons such as PRE, family size, poor sales, low income, lack of trust for SSNIT, unfavorable political regime including time management account for one's participation in pension contribution. 
Exploring The Nexus Between Family Size Planning

and Retirement Planning In Ghana

\section{FACTORS THAT INFLUENCE FAMILY SIZE PLANNING}

The respondents were asked closed ended questions on whether they considered age, gender, education, number of children, employment, sector of work, income and PRE influence family size planning oriented. This section discusses how level of education and income influence family size planning.

\section{Educational differences in family size planning}

An individual's age is capable of influencing his/her involvement in family size planning. Given this possibility, the study investigated the extent to which age influences family size planning. This study did not find age differences in the preference for manageable family size planning ( $p$-value=1.000). Most workers (96.8\%) with tertiary level of education intimated that age influenced family size planning, ( $p$-value $=0.000)$. No sex or gender difference was found in the preference of a small family size ( $p$-value $=0.792$ ) (See Table 2 for details). However, the educational level of the planners influenced the consideration of the number of children ( $p$-value $=0.000$ ). Individuals from all educational backgrounds placed similar emphasis on the income of retirement planners in tandem with retirement planning ( $p$-value $=0.050)$. Yet, individuals with tertiary level of education stressed PRE of planners ( $p$-value $=0.005$ ). Workers who had attained pre-tertiary (92\%) and tertiary (87.3\%) emphasized the role of education in family size planning uptake considerations.

Table 2

Chi-square Test: Age differences in family size planning

\begin{tabular}{lcccc}
\hline $\begin{array}{l}\text { Factors considered in } \\
\text { family size planning }\end{array}$ & $\begin{array}{c}\text { No formal } \\
\text { education }\end{array}$ & $\begin{array}{c}\text { Pre-tertiary } \\
\text { education }\end{array}$ & $\begin{array}{c}\text { Tertiary } \\
\text { education }\end{array}$ & p-value \\
\hline Age & $73.0 \%$ & $91.9 \%$ & $96.8 \%$ & 0.000 \\
Gender & $62.3 \%$ & $87.5 \%$ & $65.4 \%$ & 0.792 \\
Education & $91.9 \%$ & $88.9 \%$ & $90.1 \%$ & 0.000 \\
Number of children & $73.1 \%$ & $61.3 \%$ & $97.8 \%$ & 0.005 \\
Employment & $90.1 \%$ & $95.5 \%$ & $91.3 \%$ & 0.283 \\
Sector of work & $84.8 \%$ & $98.0 \%$ & $84.8 \%$ & 0.154 \\
Income & $86.0 \%$ & $94.0 \%$ & $99.1 \%$ & 0.050 \\
PRE & $65.0 \%$ & $92.0 \%$ & $87.3 \%$ & 0.005 \\
\hline
\end{tabular}

Note: $\alpha=0.05$. 


\section{Income differences in family size planning}

An individual's age is capable of influencing his/her involvement in family size planning. Given this possibility, the study explored the extent to which age influences family size planning. Most respondents within the low income class (62.3\%) intimated that age influenced family size planning ( $p$-value $=0.000)$. In the same vein, workers in the low income, middle income and high income classes placed considerable emphasis on number of children ( $p$-value $=0.056$ ). Income level was found to influence the consideration of PRE in the low income (79.7\%), middle income (78.9\%) and high income (99.0\%) classes. However, gender ( $p$-value $=0.154)$, education $(p$-value $=0.293)$, and employment $(p$-value $=0.089)$ did not influence family size planning.

Table 3. Chi-square Test: Income differences in family size planning

\begin{tabular}{lcccc}
\hline $\begin{array}{l}\text { Factors considered } \\
\text { in family size planning }\end{array}$ & Low income & Middle income & High income & p-value \\
\hline Age & $62.3 \%$ & $88.9 \%$ & $97.8 \%$ & 0.000 \\
Gender & $91.9 \%$ & $61.3 \%$ & $91.3 \%$ & 0.154 \\
Education & $73.1 \%$ & $95.5 \%$ & $84.8 \%$ & 0.293 \\
Number of children & $90.1 \%$ & $98.0 \%$ & $46.7 \%$ & 0.056 \\
Employment & $84.8 \%$ & $99.0 \%$ & $99.1 \%$ & 0.089 \\
Sector of work & $86.0 \%$ & $55.03 \%$ & $73.1 \%$ & 1.000 \\
Income & $77.0 \%$ & $94.0 \%$ & $59.0 \%$ & 0.011 \\
PRE & $79.7 \%$ & $78.9 \%$ & $89.9 \%$ & 0.002 \\
\hline
\end{tabular}

Note: $\alpha=0.05$.

In addition, the survey data was subjected to Pearson Chi-square statistics and Cramer's V test to examine whether there is any association between family size planning and retirement planning (Table 4). The Cramer's $V=0.688$ indicates a strong existing association between the two variables.

Empirical evidence exists to show that retirement planning is associated with family size planning (Caldwell, 2005; Dovie, 2018a). Further, criteria to family planning are fertility, birth spacing and family size (Karra, Canning, Hu, Ali, \& Lisser, 2016). 
Exploring The Nexus Between Family Size Planning

and Retirement Planning In Ghana

Table 4

Chi-Square statistics of family planning and retirement planning

\begin{tabular}{lccc}
\hline Tests & Value & $\begin{array}{c}\text { Degree of } \\
\text { freedom }\end{array}$ & Asymp. Sig. (2-sided) \\
\hline Pearson Chi-Square & $403.222 \mathrm{a}$ & 10 & .000 \\
Cramer's V & 0.688 & 10 & .000 \\
$\mathrm{~N}$ of Valid Cases & 442 & & \\
\hline
\end{tabular}

Source: Field data, 2016.

\section{FORMATION OF SOCIAL RELATIONSHIPS}

Social relationships can be formed at the individual and group levels with the devotion of funds, time and effort being of core essence. At the individual level, it may be formed with children, siblings, cousins, nephews and nieces, spouses, parents, uncles and aunties, house maids and servants, significant others, etc. Similarly, at the group level, it is attained by virtue of joining associations albeit professional, quasi professional or non-professional exemplified by Field engineers, Ghana Institute of Surveyors, Ghana Institute of Builders, Rotary Club, Club 50, Community 1 Market Traders Association, Community 2 Market Traders Association, Community 5 Market Traders Association, Communities 5 and 6 Taxi Drivers' Union, etc.

The formation of social relationship stems from respect as well as empathy for others with regard to obligation, responsibility, plight including the experience of similar predicaments before, etc. The latter point makes the support provided a 'give back' phenomenon especially in the case of siblings, cousins, nephews, nieces and significant others. Social relationship building involves counselling or advice, accommodativeness, appreciation by parents and children and/or wards. An informal male participant reported that social relation formation is made up of counselling/advice, accommodativeness from the supporter to the supported and appreciation from the supported.

Taking care of children has implications for parents, the reverse also applies. Significantly, it brings about cordiality. Parents need to get close to their children. Children also should know what their parents do including their secrets. The act of children fearing their parents is not good. Such fear is caused by the nature of parents, 
displaced aggression, way of training, age and sex discrimination, shouting unnecessarily on children including beating them.

Parents must provide their children's needs where necessary namely school fees, build rapport between them, the children and their teachers. When needed, parents should go to their children's schools to explain their predicaments to the school officials rather than let children go alone. Capital formation through susu also enables the financing of children's education. With respect to personal effects, if the parents do not have the resources to acquire that, they should explain to the children in a humane manner. The formation of social relationships requires of the builders (e.g., parents, guardians, siblings, and significant others) to engage in certain acts with their children and/or wards. The following quotes confirm these assertions:

The money I obtain from susu collection I used to pay my children's school fees and so my children are my retirement investment (Informal female).

All my monies go into my 4 children's school fees and I have nothing left for other investments (Informal female).

Say to the child, I will buy you the dress when I receive the money I am expecting (Informal male).

Show love, watch television programs with children and wards, correct them when they are wrong, answer their burning questions, be very close to them, and take them out to the park, zoo, children's park, national theatre. It all has to do with communication. If your child sees you and panics or is afraid of you, it is not the best (Formal female).

Parents look after their children for them to look after them in return. However, it is not always that children have to be supported for purposes of reciprocity. Rather, they should be supported so that they can cater adequately for themselves afterwards. This perception takes away the notion of 'give and take' or 'social insurance' in this context. Thus, a Formal sector female claimed:

Now parents need not invest in their children with the objective of they becoming their old age security, rather parents and guardians should plan for their own retirement while taking care of their children.

The statements above suggest that there are 2 paradigms to childcare outcomes namely social insurance and non-social insurance. The first one perceives children as social insurance, a situation in which children are obliged to care for their parents in 


\section{Exploring The Nexus Between Family Size Planning and Retirement Planning In Ghana}

return for care earlier received. To the contrast, the non-social insurance paradigm is opposed to using children as social insurance. Instead, it advocates for adequate retirement preparation as an 'insurance' against old age. It is worth reiterating the fact that parents invest in their children with both financial and material resources. However, the latter becomes the norm in the absence of the former. Investing in children has its downturns, which mostly female workers circumvented with the trading of their material resources for cash. The following observations have been made to this effect:

During times of financial difficulties when my children's school needs were outstanding, I often traded my Hollandaise and GTP wax prints for money with the promise that if I return the money I take them back or else that ends it (Informal female).

For those of us whose pays are meagre, it is not easy ooo. The last time, I had to barter trade five of my African wax prints because of my children's school fees (Formal female).

Beyond the level of children, siblings, nephews and nieces and significant others are supported for diverse reasons such as obligation, responsibility, learning process, counteract impending burden, being benevolent, sympathy and avoidance of dependency. The care for siblings is as important as that for own children. Relationship builders sometimes act as proxies for others by performing their duties on their behalf due to financial constraints or other reasons. People care for others as an experimentation of their life later in the life course, especially as parents.

For instance, a formal male who cared for his siblings made the following statement:

I care for them in my father's stead, since it is his responsibility to care for them, to avoid them being a burden to me and also as a learning process of caring for my own children later on and being a benevolent person.

With regard to nephews and nieces, the key reason is related predominantly to the avoidance of dependency. Hence, an informal sector male mentioned that:

Supporting nephews and nieces through care or provision of material things is mostly undertaken to curtail dependence of the supported on the supporters, though occasionally they support the supporter when the need arises. 
From the viewpoint of significant others, supporting them is aimed at the act of benevolence, and based on prior experience of similar situation(s). For example, the following observations were made:

I support parents in the care of their children in order to avoid envy and jealousy against own children (Formal male).

It is because I have been in a similar situation before, where my parents were not in the position to support me because they were very poor and I had to survive in school with the support of uncles, aunties and significant others (Informal female).

I have been in a similar situation before but succeeded with the support of others. So I have endeavored to do good to children in such predicaments and by extension others who are in need (Formal female).

I support those I can because of the sympathy I have for the poor and needy (Formal female).

Some workers have their nephews and nieces as well as other members of the general Ghanaian society living with them. The former are obliged to perform household chores and in return their needs are catered for.

A number of the participants concentrated on the enormity of the benefits of social relationship formation for builders and the beneficiaries. At the individual level, it entails doing good, blessings, protection, etc. This is indicative of alignment issues that concentrate on the purpose and goals of the relationships once formed. For the builders, these benefits entail social interaction, physical and spiritual protection, cordial relationship establishment and maintenance, avoidance of envy and jealousy against own children, avoidance of dependency of the supported on the supporter, attending to the plights of the vulnerable and needy in society, and/or been sympathetic towards the plight of others including gratification. In lieu of these were the following:

Helping others generates blessings verbally and prayers that serve as a form of protection at some point in time (Formal male).

Relationships that are not cordial may be due to unappreciative mothers, while the cordial ones are due to appreciative mothers. This is because some mothers when the fathers give them monies to be given to the children/wards, they behave as if it is directly coming from them and not the fathers. This makes the fathers look bad before the children (Formal male). 


\section{Exploring The Nexus Between Family Size Planning and Retirement Planning In Ghana}

For the beneficiaries, the benefits encompass social interaction, cordial relationship establishment and maintenance, financial support towards education from Junior High School (JHS) through to the tertiary levels namely higher national diploma, first and second degrees, etc and career accomplishments. Also, a couple of these benefits transcend benefactors and beneficiaries such as social interaction, cordial relationship establishment and maintenance among others.

The process of social relationship formation may entail two phases namely initial and termination phases. During the initial phase, the individual is supported through education or career training until he/she has completed schooling, e.g. JHS to Senior High School (SHS), and SHS to the tertiary level including completion of apprenticeship (e.g. dressmaking/fashion designing, hairdressing, vulcanizing, etc). When the educational training process is completed and the 'assisted' individual becomes gainfully employed, which denotes the termination phase.

At the group level, it may entail persistence beyond the retirement transition. Noteworthy is that individual workers belong to several associations simultaneously. The findings demonstrate the fact that some informal sector workers are members of at least three associations. For instance, Asanteman Association, Tema Market Women's Association, Tema Widows' Association as well as church welfare groups. For instance:

I belong to the Ghana Institute of Surveyors, Ghana Institute of Builders, Rotary Club and Club 50 in Ho. I will still belong to these associations even when I retire at 60 years (Formal male).

I belong to the Community 2 market association.

I belong to the Asanteman kuo, Tema widow's association and market women's association (Informal female).

I was once a part of the market women's association but I stopped because of mistreatment and disagreement over space (Informal male).

This may be the case due mostly to the benefits of joining those associations. The benefits of joining associations are numerous and entail the contribution of financial resources when a member loses a family relation, the provision of needed support in other situations including escort to programs such as funerals, outdooring, engagements and weddings, etc, provision of information regarding investment avenues, support for sickness and death of members. Belonging to voluntary associations serves as a two-edged sword coping mechanism in both pre- and post-retirement 
life. In the pre-retirement life, voluntary associations are beneficial in terms of the points raised above, whereas in post-retirement life they are beneficial from the viewpoint of companionship provision in cases of sickness and eventual death. Workers are both human beings and social beings who need companionship and friendship in one form or the other. The proceeding voices allude to the connection between retirement planning and association membership. A member noted that: "joining the market women's association is very beneficial. My mother died 5 years ago at 84 years. The association contributed financially to her burial" (Informal female).

In confirmation, the queen mother of the Community 2 Market Association notes that:

The association ensures access to information related to insurance, savings, sika plan and many more. In which case the leader is usually first informed and who then informs the members. It also makes contributions to support members in times of ill-health, outdooring and bereavement.

\section{DISCUSSION}

Preparation towards retirement also entails family planning and social relationship building. These take three distinct forms such as having a manageable family size, care for own children, care for siblings and/or cousins as well as joining association(s). A gradual shift pertains to smaller families with retirement planning in focus. Also, annexed to family planning is social relationship building, both of which have implications for later life planning. According to Dovie (2018a), these can be collectively pursued. This is however oftentimes dependent on the availability of the requisite planning information. Hence the argument that retirement planning information and preparation towards life in old age are inseparable (Dovie, 2018b). Women in developing countries increasingly have desires for smaller families as a result of which contraceptive use increased, while fertility rates dropped. However, demographic surveys intimate that the actual family size in most developing countries remains greater than the desired family size. This is indicative of the gap between the real and the ideal family size prevalent in sub-Saharan Africa. Yet, also critical to preserving a woman's life and health, are her ability to control the timing, spacing and total number of children (Barot, 2008). Sun et al. (2007, p. 57) asserted that personal retirement planning behaviour is a function of access to investment information. Infor- 


\section{Exploring The Nexus Between Family Size Planning and Retirement Planning In Ghana}

mation provided by employers, financial consultants, family or friends seem to be the most influential components of decision making.

Planning family sizes lead to the conservation of funds for onward investment or channeling into retirement plans and/or portfolios. Having a smaller family size becomes a retirement aspiration for the workers. Ideally, the whole process of retirement planning which commences with family size planning, has implications for retirement preparation and the associated benefits (Dovie, 2018a). The progress in retirement planning causes a structural change that entails the issue of the impact of family planning and vice versa, particularly with implication for retirement planning in terms of financial asset mobilization (Dovie, 2019b). As a result, Caldwell (2005) demonstrates that thus, the pressure to have fewer children results principally not from forward-looking educated parents but from forward-looking investing parents (p. 736). Financial resources are mobilized through shares, susu, equities (Osei-Assibey, 2014), savings (Osei-Assibey, 2014; Quartey \& Prah, 2014), pension contributions, and investments into mfund, epack (Dovie, 2017) among several others.

The relationship-focused strategy pertains to the building of relationships that could be depended on in old age. The process of social relationship formation is constituted by two phases such as initial and termination phases. It is in the initial phase that individuals are supported through education or career training to completion. In consequence, securing a gainful employment marks the termination phase. Social relationship building at both the individual and group levels, depict persistence beyond the retirement transition. Therefore, by building positive relationships with others, individuals will be happier and more fulfilled and feel more supported, supportive, and connected (Freifeld, 2013).

The results show that family size planning is a retirement planning aspiration, making it a retirement planning prerequisite. The notion of family size planning has been alluded to by Atchley (2000) and Caldwell (2005). The findings are suggestive of two paradigms to childcare outcomes: social insurance and non-social insurance. The first one perceives children as social insurance, a situation in which children are obliged to care for their parents in return for care they received early on in life. It is in this context that Caldwell (2005) argues that children obtain insurance value especially in times of old age. To the contrast, the non-social insurance paradigm is opposed to the dependence on children as social insurance. Thus, it advocates for adequate retirement preparation as an 'insurance' against old age. By and large, this paradigm is comparatively accommodative to the plight of 'childless' workers and planners. 
The notion of social insurance may be said to be direct and indirect. The direct social insurance web is situated around children whereas the indirect one comes from siblings, nephews and nieces, significant others and association members. These may provide financial support in old age but also companionship and friendship. Further, gifts of goods or services and later reciprocation allow the creation of a security system of mutual obligations (Caldwell, 1976, p. 339). Yet, it may not be a given in contemporary times that children must be supported for purposes of the notion of reciprocity. Instead, this could be done to enable them care for themselves, barring the notion of 'give and take' or 'social insurance'. Annexed to this phenomenon is social relationship paradigm.

\section{CONCLUSION}

The emerging issues in the study highlight the scope of retirement planning as expanded especially with respect to family planning and social relationship building. Access to pension information and preparing towards life in old age are inseparable. This is essential because information dissemination and resultant literacy may have a great impact on workers' savings behavior including family size planning.

This study did not find age differences in the preference for manageable family size planning ( $p$-value $=1.000$ ). There was no sex or gender difference was found in the preference of a small family size ( $p$-value $=0.792$ ). The educational level of the planners influenced the consideration of number of children ( $p$-value $=0.000)$, whilst workers placed similar emphasis on the income of retirement planners in tandem with retirement planning ( $p$-value $=0.050)$. Also, planners with tertiary level of education stressed PRE of planners ( $p$-value $=0.005$ ). Workers in the low income, middle income and high income classes placed considerable emphasis on number of children $(p$-value $=0.056)$

The findings show that the desired family size ranges between 1 and 5 in terms of the number of children had. Formal (76.2\%) and informal (23.8\%) sector workers, note that the highest number of children should be 5 . Cramer's $V=0.688$ is a reflection of the fact that a strong association exists between family size planning and retirement planning.

There are 2 distinct paradigms to childcare outcomes. They are social insurance and non-social insurance. The first paradigm perceives children as social insurance, 


\section{Exploring The Nexus Between Family Size Planning and Retirement Planning In Ghana}

and the associated notion of reciprocity for care earlier received. The second paradigm shows that siblings, nephews and nieces and significant others are supported for purposes of obligation, responsibility, learning process, counteract impending burden, being benevolent, sympathy and avoidance of dependency.

The attendant social relationships are formed at the individual and group levels interspersed with the devotion of funds, time and effort being of core essence. At the individual level, it is formed with children, siblings, cousins, nephews and nieces, spouses, parents, uncles and aunties, house maids and servants, significant others, etc. At the group level, it is constituted by the joining of diverse associations albeit professional, quasi professional or non-professional. The formation of social relationships is based on respect, empathy, obligation, responsibility, including the experience of similar predicaments. Social relationship formation entails counselling or advice, accommodativeness, as well as appreciation.

The benefits social relationship formation comprise social interaction, cordial relationship establishment and maintenance, financial support towards education and career accomplishments.

The social relationship formation pathway consists of two phases namely initial and termination phases. The individual at the individual level is supported through education or career training. Completion and securing of gainful employment signifies the termination phase.

At the group level dimension is persistence beyond the retirement transition, expressed in joining associations. Belonging to voluntary associations serves as a twoedged sword coping mechanism in both pre- and post-retirement life.

Retirement planners' manageable family size planning with the expected number ranging between 1 and 5 children, could be said to be an aspiration in the context of this paper, as it depicts a goal in in itself. The essence of which is to bear a number of children who can be cared for adequately notwithstanding other exigencies including the phenomenon of retirement planning. Such an aspiration is in line with Atchley's (2000) postulations, particularly the aspiration dimension of the act of family planning. Hence, retirement planners aspired to have smaller and manageable family size, the attainment of which is a valuable achievement. This aspiration is anchored by the provision and access to PRE.

The articulation of a small family size planning is consistent with Caldwell's (2005) intimation for small family sizes in non-western societies including Africa and Ghana. Although, family size planning has been considered as the preserve of population 
growth concern, the findings show that family size planning is worthy of consideration in the context of retirement planning.

The findings contradict Caldwell's (2005) postulation of children serving as old age security of social insurance for their parents and/or guardians. Since the social relationship formation dimension denounces the reciprocity tangent of children, wards or significant others', yet emphasizes the latter being given firm grounding in life.

It is concluded that PRE significantly influences preparing towards post-retirement life. Although, other intervening factors such as competing financial resources and priority orientation inhibit the extent of this influence. Indeed, family size planning correlates significantly ( $p$-value $=0.688$ ) with retirement planning. However, associated with this is social relationship building for onward use and/or benefits. In other words, family planning and its family size are connected to social relationship building and/or social networking pathways within the context of retirement planning. They have implications for financial risk taking and the related risk aversion with cultural underpinnings.

Some gaps and directions for the future have been identified. For instance, the scarcity of relevant studies on family size planning and retirement planning. This study focused on family size planning, not targeted specifically at maternal health and child mortality. Thus, further studies need to be conducted in this grey area. Further, the most significant barriers to family size planning is the lack of cooperation between couples with regards to the spacing births and by extension limiting the number of children had. Improvement in family size planning education should be implemented through local approaches and national policy, while appreciating the cultural context.

Noteworthy is that only worker groups who agreed to participate were included and that the response rates varied substantially between sectors. Furthermore, no behavioral observations were used to confirm the measure(s).

\section{REFERENCES}

Aboderin, I. (2004). Decline in Material Family Support for Older People in Urban Ghana. The Journal of Gerontology, Series B, Psychological Sciences and Social Sciences, 59(3), S128-S137. 


\section{Exploring The Nexus Between Family Size Planning}

and Retirement Planning In Ghana

Aboderin, I. (2005). Conditionality and limits of filial obligations. Working paper no. WP205. Retrieved July 21, 2017 from http://www.ageing.ox.ac.uk/files/workingpaper_205.pdf

Aboderin, I. (2006). Intergenerational support and old age in Africa. New Brunswick, New Jersey: Transactions.

Ackah, C., \& Baah-Boateng, W. (2012). Trends in growth, employment and poverty in Ghana. In C. Ackah, C. \& E. Aryeetey (Eds.), Globalisation, trade and poverty in Ghana (pp. 33-49). Accra: Sub-Saharan Africa Publishers.

Ackah, C., Turkson, F. E., \& Opoku, K. (2012). Trade cost and intra-regional trade flows in ECOWAS. J West Afr Integr, 1(1), 1-43.

Addai I. (2011). Estimating gender earnings gaps in the informal sector Kayayei Labour Market: Micro-level empirical evidence from Kumasi, Ghana. Ghana Social Science Journal, 8(1\&2), 92-105.

Agbobli, A. D. (2011). Pensions: The new instrument perspective for retirement planning. Accra: Mork Impressions.

Atchley, R. C. (2000). Social forces and aging (9th ed.). Belmont, CA: Wadsworth.

Amoako-hene, M. (2011). Information management: The nemesis of Ghanaian governments. Ghana Social Science Journal, 8(1\&2), 150-173.

Barot, S. (2008). Back to basics: the rationale for increased funds for interventional family planning. Retrieved December 12, 2019 from http://www.guttmacher.org

Bazeley, P., \& Jackson, K. (2014). Qualitative data analysis with Nvivo (2nd ed.). Thousand Oaks, CA: Sage.

Bryman A. (2008). Social research methods (3rd ed.). Oxford: Oxford University Press.

Caldwell, J. C. (1976). Toward a restatement of demographic transition theory. Population \& Development Review, 2(3/4), 321-366.

Caldwell, J. C. (1978). A fertility theory: From a plateau to destabilisation. Population \& Development Review, 2(3), 321-366.

Caldwell, J. C. (2005). On net intergenerational wealth flows: An update. Population \& Development Review, 31(4), 721-740. 
Chen, M. A. (2007). Rethinking the informal economy: Linkages with the formal economy and the formal regulatory environment. In José A. Ocampo \& K.S. Jomo (eds.), Towards full and decent employment (preface, pp. 234-254). New York: Zed Books.

Daatland, S. O., \& Herlofson, K. (2003). 'Lost solidarity' or 'changed solidarity': a comparative European view of family solidarity. Ageing and Society, 23, 537-560.

De-Graft Aikins, A., Kushitor, M., Sanuade, O., Dakey, S., Dovie, D. A., \& KwabenaAdade, J. (2016). Research on aging in Ghana from the 1950s to 2016: A bibliography and commentary. Ghana Studies Journal, 19, 173-189.

Demographic Health Survey (2008). Ideal family size - The DHS program. Retrieved December 6, 2019 from https://dhsprogram.com

Doh, D., Afranie, S. \& Bortei-Doku Aryeetey, E. (2014). Expanding social protection opportunities for older people in Ghana: A case for strengthening traditional family systems and community institutions. Ghana Social Science Journal, 11(1), 26-52.

Dovie, D. A. (2017). Preparations of Ghanaian formal and informal sector workers towards retirement. Unpublished Doctoral Thesis, University of Ghana, Accra.

Dovie, D. A. (2018a). Systematic preparation process and resource mobilisation towards post-retirement life in urban Ghana: An exploration. Ghana Social Science Journal, 15(1), 64-97.

Dovie, D. A. (2018b). Financial literacy in an African society: An essential tool for retirement planning. Contemporary Journal of African Studies, 5(2), 26-59.

Dovie, D. A. (2018c). Utilization of digital literacy in retirement planning among Ghanaian formal and informal sector workers. Interações: Sociedade e as Novas Modernidades, 34, 113-140. https://doi.org/10.31211/interacoes.n34.2018.a6. Special Issue on (In)Equalities and Social (In)Visibilities in the Digital Age.

Dovie, D. A. (2019a). Assessment of how house ownership shapes health outcomes in urban Ghana. Societies, 9(43), 1-18. https://doi.org/10.3390/soc9020043. Special Issue Families, Work and Well-being. 


\section{Exploring The Nexus Between Family Size Planning and Retirement Planning In Ghana}

Dovie, D. A. (2019b). Financial assets. In D. Gu, \& M.E. Dupre (Eds.), Encyclopedia of gerontology and population Aging. New York: Springer Publishing Company.

Dovie, D. A. (2019c). Utilizing retirement planning as leverage for age reduction among workers. In Ł. Tomczyk \& A. Klimczuk (Eds.), Between successful and unsuccessful ageing: selected aspects and context (pp. 23-57). Kraków: Uniwersytet Pedagogiczny wKrakowie. https://doi.org/10.24917/9788395373718.2

Dovie, D. A., Ayimey, I. R., \& Adodo-Samani, P. (2018). Pension policy dimension to Ghanaian workers' housing needs provision. Interações: Sociedade e as Novas Modernidades, 35, 30-56. https://doi.org/10.31211/interacoes.n35.2018.a2

Dugbazah, J. (2012). Gender, livelihoods and migration in Africa. USA: Xlibris Corporation.

Employee Benefits Research Institute (2019). 2019 retirement confidence survey summary report. Retrieved June 15, 2019 from http://www.ebri.org

Freifeld, L. (2013). 8 tips for developing positive relationships. Retrieved August 4, 2019 from https://trainingmag.com/content/8-tips-developing-positive-relationships/

Ghana Statistical Service (2014). 2010 population and housing census: District analytical report - Accra Metropolitan. Retrieved October 2, 2015 from http://www. statsghana.gov.gh/docfiles/2010_District_Report/Greater\%20Accra/AMA.pdf

Ghana Statistical Service(2013). 2010 Population and housing census report: The elderly in Ghana.

Greenwald, M. \& Associates (2013). The decision to retire and post-retirement financial strategies: A report of eight focus groups. The Society of Actuaries. Retrieved June 23, 2019 from https://www.soa.org/globalassets/assets/files/research/projects/research-2013-decision-retire.pdf

Holzmann, R., \& Hinz, R. (2005). An international perspective on pension systems and reform: old age income support in the $21^{\text {st }}$ century. Washington D.C.: The World Bank. 
Karra, M., Canning, D., Hu, J., Ali, M., \& Lisser, C. (2016). Community-based financing of family planning in developing countries: A systematic review. Studies in Family Planning, 47(4). https://doi.org/10.1111/sifp.12000

Litwin, H. (2010). Social networks and well-being: A comparison of older people in Mediterranean and non-Mediterranean countries. Journals of Gerontology Series B-Psychological Sciences and Social Sciences, 65, 599-608.

Moody, H. R. (2010). Ageing: Concepts and controversies (6th ed.). Los Angeles, CA, USA: Fine Forge Press.

Moore, D. R., \& McCabe, G. P. (1993). Introduction to the practice of statistics (2nd ed.). New York: W.H. Freeman and Company.

Novak, M. W. (2006). Issues in ageing. Boston: Pearson.

Osei-Assibey, E. (2014). Resource mobilisation through the capital market in Ghana. In P. Quartey, E. Bortei-Doku Aryeetey, \& C. G. Ackah (Eds.), Domestic resource mobilisation for inclusive development in Ghana (pp. 193-226). Accra: Sub-Saharan Publishers.

Palmer, R. (2007). Education, training and labour market outcomes in Ghana: A review of the evidence. RECOUP Working Paper 9.

Perneger, T. V., Courvoisier, D. S., Hudelson, P. M., \& Gayet-Ageron, A. (2015). Sample size for pre-test of questionnaires. Qual. Life Res. 2, 147-151.

Quadagno, J. (2014). Ageing and the life course: An introduction to social gerontology (6th ed). Boston: McGraw Hill.

Quartey, P., \& Prah, F. (2014). Trends in domestic savings in Ghana. In P. Quartey, E. Bortei-Doku Aryeetey, \& C. G. Ackah, (Eds.). Domestic resource mobilisation for inclusive development in Ghana (pp. 58-95). Accra: Sub-Saharan Publishers.

Rappaport, A. (2017). How can family fit into your retirement plans? Retrieved May 24, 2019 from https://www.forbes.com/sites/pensionresearchcouncil/2017/06/02/ how-can-family-fit-into-your-retirement-plans/\#62c460ed650b

Round, D. (2009). The boundaries between informal and formal work. Retrieved October 30, 2015 from http://www.beyondcurrenthorizons.org.uk 
Sun, W., Barboza, G. \& Richman, K. (2007). Preparing for the future: Latinos' financial literacy and retirement planning. The Business Journal of Hispanic Research, 1(2), 54-68.

Tonah, S. (2009). The challenge of ageing in rural and urban Ghana. In S. Tonah (Ed.), Contemporary Social Problems in Ghana, Accra: Yamens Press Limited.

Tsikata, D. (2015). Like your own child: Employers' perspective and domestic work relations in Ghana. In C. R. Rodriques, Tsikata, D., \& A. Adomako Ampofo (Eds.), Trans-Atlantic feminists: Women and gender studies in Africa and the Diaspora (pp. 189-211). London: Lexington Books. 